\title{
Antibacterial Activity Studies of Essential Oils from Red Sage (Lantana Camara)
}

\section{Omoyemi Oluwatosin Ajayi}

1Department of Chemistry, Federal University of Technology, Akure, Nigeria;

\section{Abdullah Tunde Aborode}

Department of Chemistry, University of Ilorin, Ilorin, Nigeria;

\section{Opeyemi Isaac Subuloye}

Department of Chemistry, Federal University of Technology, Akure,

\section{Abayomi Oyeyemi Ajagbe}

Department of Anatomy, College of Health Science, Nile University of Nigeria,

\section{Mika Sillanpaa}

Institute of Research and Development, Duy Tan University, Da Nang 550000, Vietnam;

Iwuozor Kignsley Ogemdi

Department of Chemistry, University of Lagos, Lagos, Nigeria

\section{Babatunde Samuel Obadowo}

Department of Chemistry, University of Toledo, Ohio, USA

Ridwan lyanu Arinola ( $\sim$ arinolaridwan@gmail.com )

Department of Microbiology, Ekiti State University, Ado-Ekiti, Nigeria

\section{Gaber El-Saber Batiha}

Department of Pharmacology and Toxicology, Faculty of Veterinary Medicine, Damanhour University, Egypt

\section{Research Article}

Keywords: Essential oil, Lantana camara, Antibacterial activity

Posted Date: February 9th, 2022

DOI: https://doi.org/10.21203/rs.3.rs-1299145/v1

License: (c) (1) This work is licensed under a Creative Commons Attribution 4.0 International License. Read Full License 


\section{Abstract}

Essential oils are important source of rich medicinal compounds. They are highly volatile, aromatic compounds from natural origins. The essential oils cause the hydrophobility of the bacteria cytoplasm, resulting to the cell wall degradation. The recent activity studies of Lantana camara have mapped out the need to investigate the antibacterial potency of its essential oil. Herein, the result and discussion of the characterization with their antibacterial activity of Lantana camara was reported; the Minimum inhibitory concentration (MIC) on the bacteria (Positive and Negative Gram) with Ciprofloxacin a known antibiotic as the positive control. The broth and agar diffusion method were used in estimating Zone of the inhibition. Oil show moderate antibacterial potency with respect to each of the bacterium used; the potency tends to increase considerably with increase in concentration $(25 \%<50 \%<80 \%<100 \%)$. The zone of inhibition exhibited by the assay at $100 \%$ concentration of the essential oil on E. coli was the closest shown to that of the control (ciprofloxacin), also the MIC on E. coli at $100 \%$ concentration of the essential oil was greater than that of the control (ciprofloxacin). Consequently, essential oils from lantana camara becomes a wellspring of antibiotics for restraining bacteria action.

\section{Introduction}

Natural products are predominant for the design of novel drugs in the prevention and treatment of disease [1]. Over the years, the people have exploited their usages due to their availability, low cost, effectiveness, low toxicity [2]. Medicinal plants since ancient time have provided huge sources of medicine [3]; thereby hone the modern medicine with many plant-based therapeutic agents [4]. In India and Africa alone over 6000 plants are exploited for traditional medicine [5].

Essential oils are extracts from complex mixtures of diverse parts of certain plant and animal species [6]. They are highly concentrated volatile substances with peculiar and potent therapeutic activity [7]. Due to their low toxicity to mammals, we acknowledge for their pharmacological and therapeutic properties [8]. The chemicals constituent of essential oils are secondary metabolites; terpenes, terpenoids, phenylpropenes, and others based on chemical structure, which play a core role in their strong bactericidal activity $[6,9]$. They are fused into edible films as an active composition in food safety and packaging to enhance food quality and shelf live by inhibiting microbial growth [10].

The plant Lantana camara (Verbanaceae) is indigenous to subtropical and tropical regions and is generally known as red or wild sage [11]. It is an ever green intense smelling shrub with diverse flower colors and stout recurred prickles [12]. The therapeutic potential of Lantana camara comes as a result of its bioactive compounds which have been exploited for antibacterial, antipyretic, larvicidal, insecticidal, and antimicrobial purposes $[13,14]$. Essential oil extract of Lantana camara is used in conventional medication framework for the treatment of various diseases [15]. This include antiseptic for wounds [16], disorders [17], respiratory problems [8], antiseptic and antibiotic applications [18]. 
The antimicrobial activity of an essential oil involved disruption of bacterial structures by causing hydrophobicity between the cytoplasm and external envelope of the cell [19]. This increased permeability and degradation of the cell wall, essential oils is difficult to be removed from the bacterial cell membrane [20]. In addition, this resulted to the leakage of the cell contents and diminished the intracellular ATP pool [21].

Essential oil contains hydrophobic antimicrobial compounds; the Gram-negative bacteria have hydrophilic lipopolysaccharides (LPS) outer membranes which impede the action of the hydrophobic essential oil constituent making them less affected compare to the Gram-positive bacteria which show more affinity [22-24].

In view of this, this research study is mapped out to study the antibacterial activity of lantana camara essential oil through the determination of the chemical composition of essential oil, zone inhibition of the action of the bacteria and the characterization of the sample with Ciprofloxacin a known antibiotic as the positive control in order to obtain the antibacterial potential of the essential oil and its relation with the antibiotic.

\section{Methodology}

\section{Sampling and collection of plants}

The Lantana camara leaves were sourced locally within FUTA south-gate, around Abavicinity, Akure Nigeria, where it is serves as a weed and a plant of no interest. They were collected by carefully uprooting from the vegetation of different cluster of the weed around the bushes to ensure homogeneity of sample. The plant was authenticated at the Department of Crop, Soil, and Pest Management, The Federal University of Technology, Akure, Nigeria. Subsequently, the plant parts (leaves and part of the stem close to the leaves) were carefully separated and washed lightly to remove all forms of dirt.

\section{Isolation of L. camara essential oils}

The hydro-distillation method was engaged for the extraction process. A glass clevenger-type apparatus was connected to a heating mantle; this consists of $2000 \mathrm{ml}$ round bottom flask enclosing $2.70 \mathrm{~kg}$ of the raw material and 1.5 liters of water. The setup was for 4 hours at an optimum temperature $750^{\circ} \mathrm{C}$, which was repeated five consecutive times to have maximum yield. The resulting liquid (essential oil) was collected in a scaled, sterile amber glass vial [25]. The essential oil was kept in the refrigerator to avoid vaporization until used for bactericidal activities, UV analysis and GC-MS analysis.

The yield of the essential oil is estimated as;

Yield $=$ wt. of oil $x 100(\mathrm{~g} / \mathrm{g}) /$ Wt. Of lantana camara leaf collected 
The oil extract from the lantana camara leaveswas analyzed and characterized by UV-visible spectroscopy and GC-MS. The whole reagent used for this analysis was of analytical grade and prepared according to the manufacturer's specification.

\section{GC-MS Analysis}

The essential oil was scanned over UV/Visible spectrophotometer within the range of $280 \mathrm{~nm}$ to $900 \mathrm{~nm}$ to measure the absorbance using UV-Vis 1800 series machine.

\section{GC-MS Analysis}

A report was adopted for the GC-MS analysis of L. camera oil [26]. The GCMS-QP2010 obtained from Japan was employed for the characterization. The initially oven temperature was set at $50^{\circ} \mathrm{C}$, which was raised gradually to $250^{\circ} \mathrm{C}$. The column was injected $1 \mu$ l of the L. camera oil extract and $99.99 \%$ pure helium carrier gas was passed through for $1.2 \mathrm{ml} / \mathrm{min}$. The MS detector pickup the distinctive peak for indentified compounds in conformity with the retention time and was quantified my measuring the peak are. The data obtained from the peaks spectra were compared with data from the library (NIST14).

\section{Method Of Antibacterial Assay Sterilization of materials}

Materials: Petri dishes, syringe, swab stick, sterile borer Autoclave, Test tubes, conical flask, cotton wool. Media: Mueller-Hinton agar (MHA)

All materials and media used were sterilized in order to avoid contamination. The agar and broth media employed were also prepared as stated by the manufacturer. The media were boiled and sterilized by autoclaving at $121^{\circ} \mathrm{C}$ for 15 minutes. Also, all the glass wares were washed with soap, rinsed and dried with sterilized towel.

\section{Bacteria used}

Four (4) bacteria obtained from the Department of Microbiology, FUTA were used in the antibacterial assay of the lantana camara essential oil; Bacillus subtilis and Staphylococcus aureus which are Gram positive and Salmonella typhi and Escherichia coli II (Gram negative bacteria).

\section{Preparation of Mueller Hinton agar}

Mueller-Hinton agar (MHA) engaged for the routine antimicrobial susceptibility testing. $3.8 \mathrm{~g}$ of Mueller Hinton agar powder was dissolved with $100 \mathrm{ml}$ of de-ionized water according to manufacturer's specification. The medium was shaken well to dissolve the agar powder in the water and then sterilized in the autoclave at $121^{\circ} \mathrm{C}$ for 15 minutes [25].

\section{Antibacterial assay of oil extract}


The potential antibacterial activity of plant oil extract was carried out by modification of Geetha et al.,[27] $25 \mathrm{ml}$ of Muller Hinton agar was placed on the sterile petri dishes to solidify. A $5 \mathrm{~mm}$ diameter well was punch on the medium using a sterile borer followed with streaking the plates with bacterial culture. Upon solidification of the agar, sterile cotton swabs were used for inoculation of the bacterial cultures by spreading on the petri dish. Afterward, $0.5 \mathrm{ml}$ of varying concentration $(20,50,80$ and $100 \%)$ of the Oil extract was added to the well surface (Muller Hinton agar containing bacterial lawn). Antibiotic ciprofloxacin and wells containing distilled water was used as the positive and negative control respectively. To estimate the bacterial growth, the inoculated plates were incubated overnight at $37^{\circ} \mathrm{C}$ and the diameter in $\mathrm{mm}$ was estimated as the zone of inhibition.

\section{Minimum inhibitory concentration (MIC)}

The tube dilution method for Mueller Hinton broth was used to estimate the Minimum inhibitory concentration. $0.5 \mathrm{ml}$ of standardized density of the test organisms was added to different concentrations (20-100\%) of the plant oil extract in a series of Mueller-Hinton broth tubes for 24 hours incubation period. Hence, following visual inspection, the extract with the concentration resulting in no growth was read using a spectrophotometer (UV-Vis 1800 series machine) at $620 \mathrm{~nm}$ as the MIC.

\section{Results}

\section{Essential Oil Yield}

The variations in the quantity (yield) of the Lantana camara essential oil composition are due to variations in the genetic, climate and geographical location [28]. The L. camara extract obtained via hydro distillation gave a pale yellow essential oil with an optimum yield of $0.20 \pm 0.04 \%(\mathrm{v} / \mathrm{w})$. This extraction yield is higher than the yield of $0.19 \%$ obtained by Jawonsi and Adoga [29], $0.125 \%$ by Elansary et al.[30], in Egypt and $0.13 \%$ by Rabindra and Balendra [31] in India. This yield is less than that of $0.5 \%$ obtained by Adjou et al.[32], in Benin.

\section{UV-Visible spectra of Lantana camara essential oil}

UV-visible spectroscopy is a fast and cost-effective technique. It is used for qualitative and quantitative analysis of compounds with powerful chromophores [33]. Phenolic compounds are detected by the UVVisible spectroscopy. They give a strong color by forming complexes with iron [34]. Figure 1 and the results presented in Table 1, show the spectra of Lantana camara. The important peaks at 280nm, $320 \mathrm{~nm}$ and $360 \mathrm{~nm}$ are synonymous with presence of Xanthones, flavonoids (including flavonones, flavones and catechins) and phenolic acids respectively [35].

\section{Chemical composition of L. camara essential oil}

A reported that the variation in chemical composition characteristics and yield of an essential oil are affected with the drying method been used [36]. Similarly, the chemical profile of essential oil is affected by the time of the plant sample collection [37]. Herein, from the GC-Ms analysis report of oil extract of $L$. 
camara (figure 2) a total of 51 chemical components were reported (Table 2). However, oxygenated compounds (96.69\%) were predominant of which about $34.23 \%$ are simple sesquiterpenes. The composition of the studied Lanatana camara species is similar to a study reported Sonibare and Effiong [38]. Although, the sesquiterpenes reported in this study is lower than $37.30 \%$ and $56 \%$ reported, Saikia and Sahoo [39] and Sousa et al.,[40] respectively. Generally the major composition of the L. camara essential oil in this study was found to be $\beta$-phellandrene about $9.28 \%$ which is similar to report from Iran by Zandi-Sohani et al. [41] However the species from North Brazil shows limonene, macrene, aphellandrene, gercurcumene a-zingiberen and a-humulene has the major constituents [42]. Other major components were eucalyptol (6.68\%), a-pinene (6.26\%), 3-Carene (6.64\%), camphor (3.24\%), camphene (4.04\%), endoborneol (5.04\%), caryophyllene (4.95\%) humulene $(3.09 \%)$, bycyclogermacrene $(4.11 \%)$ and nerolidol (2.33\%). The results obtained were similar to the chemical composition of $L$. camara reported Marongiu et al. [43] and Khan et al. [44].

\section{Zone Inhibition of Lantana camara essential oil on selected bacteria}

The antimicrobial activity of $L$. camara oil extracts could also related to the various phytochemicals and peroxidases composition [45]. L. camara essential oil contains hydrophobic antimicrobial compounds [46]. Generally the Gram-positive bacteria examined have hydrophobic outer membrane which indicates strong affinity for the hydrophobic composition of the essential oil. In contrast, the outer membrane of the Gram-negative bacteria which is hydrophilic lipopolysaccharides (LPS) alters anyadaptive response to the hydrophobic essential oil $[46,47]$.

The study shows that the essential oils of extract (Figure 3) have varying antibacterial potency against the bacteria (Bacillus subtilis, Staphylococcus aureus, Salmonella typhi and Escherichia coli) at different concentration. The control (ciprofloxacin) showed significantly high zone of inhibition (16 $\mathrm{mm}$ for Bacillus subtilus, $18 \mathrm{~mm}$ for staphylococcus and Salmonella typhi and $20 \mathrm{~mm}$ for E.coli).

The antibacterial activity exhibited increases by increasing the concentration of the oil extract. $100 \%$ concentration of the essential oil showed the best antibacterial activity against all the bacteria, which is an agreement with an earlier study Sangeetha et al.[48] and Tiwari et al.[49] Bacillus subtilis shows zone of inhibition of $12 \mathrm{~mm}$, Staphylococcus aureusshows zone of inhibition of $16 \mathrm{~mm}$, which is identical to the zone of inhibition observed for Salmonella typhi, and Escherichia coli shows the highest amongst the bacteria $(18 \mathrm{~mm})$ and closest zone of inhibition to the positive control (ciprofloxacin). At $25 \%$ concentration, the oil had it weakest antibacterial activity on the bacteria. The essential oil extract of $L$. camara antimicrobial activity is as a result of its constituent; Caryophyllene, caryophyllene oxide and eucalyptol have been reported to exhibit moderate to strong activities against a wide range of bacteria [50]. Furthermore, Zoubiri and Baaliouamer [50] reported that $\beta$-caryophyllene and caryophyllene oxide possessed antimicrobial activity and caryophyllene oxide had a high activity against Candida albicans. E.coli showed the highest zone of inhibition $(19 \mathrm{~mm})$. With further studies lantana camara essential oil could be modified as a potential antibacterial for E.coli.

\section{Minimum inhibitory concentration (MIC)}


The minimum concentration of antimicrobial agent that is required to completely microbial growth refers to as MIC [51,52]. From the result (Figure 4) the least concentration of the extract resulting in no growth following visual inspection after $24 \mathrm{hrs}$ of incubation for Bacteria using a spectrophotometer at $620 \mathrm{~nm}$ was recorded as the MIC. In comparing the MIC, ciprofloxacin (control used) showed the lowest MIC for all the bacteria except for E. coli at $100 \%$ concentration $(0.015 \mathrm{ug} / \mathrm{ml})$. For all the bacteria MIC decreased progressively as the concentration increased. At 100\%, Salmonella typhi had the highest MIC $(0.026$ $\mathrm{ug} / \mathrm{ml}$ ), followed by $B$. subtilis which had MIC value of $0.023 \mathrm{ug} / \mathrm{ml}, E$. coli had MIC of $0.015 \mathrm{ug} / \mathrm{ml}$ then Staph. aureus $(0.014 \mathrm{ug} / \mathrm{ml})$. With respect to the control used, E.coli showed MIC value $(0.015 \mathrm{ug} / \mathrm{ml})$ less than that of ciprofloxacin $(0.016 \mathrm{ug} / \mathrm{ml})$, while MIC values for the rest of the bacteria were above that of the control.

\section{Conclusion And Recommendation}

The emergent of multi-drug resistant strains has launched the persistent examination of natural products for more potent new antibiotics. The activity of lantana camara essential oil extract on inhibiting bacteria growth was found to be concentration-dependent. The MIC bacteria assay, the essential oil extract showed effectiveness on the strains of bacteria in the following order Staphylococcus aureus $>$ Escherichia coli> Bacillus subtilis $>$ Salmonella typhi. Overall, the extract showed moderate growth inhibition action against bacteria when compared with standard antibiotic used Ciproflavin. The extract was found not to match the standard antibiotics already in use study, which show that there is potential for the extract, especially if the active compound is isolated, since they abound in the plant. This will be a novel way to explore indigenous plant biomass to their full potential and a sustainability way forward in unveiling new antibiotics residing in nature. However, extensive investigation of the unexplored bioactive composition of Lantana camara is needed to fully ascertain its antibacterial activity.

\section{Declarations}

\section{Ethical Approval}

The study do not involved experimentation on animals or man.

\section{Consent to participate}

$\mathrm{N} / \mathrm{A}$

\section{Consent to Publish}

All authors gave their approval for the manuscript publication.

\section{Author's contribution}

Omoyemi Oluwatosin Ajayi conceptualized the idea and was involved in performing the experiments, writing, reviewing and editing the original draft. Abdullahi Tunde Aborode; Opeyemi Isaac Subuloye; Abayomi Oyeyemi Ajagbe were involved in formal analysis and writing of the original draft 
preparation; Mika Sillanpää; Iwuozor Kingsley Ogemdi; Babatunde Samuel Obadawo; Emmanuel Adebowale Fajemisin; Gaber El-Saber Batiha finally reviewed and edited the work. Emmanuel Adebowale Fajemisin made the submission with approval of all the authors.

\section{Funding}

No funding was received for this work.

\section{Competing Interest}

All authors have no conflict of interest to disclose.

\section{Availability of data and materials}

This data herein is original research work and has not been submitted for publication elsewhere.

\section{References}

1. El-Ghazali, G. E., Al-Khalifa, K. S., Saleem, G. A., \& Abdallah, E. M. Traditional medicinal plants indigenous to Al-Rass province, Saudi Arabia. Journal of Medicinal Plants Research. 2010;4(24), 26802683.

2. Bagetta, Giacinto, Morrone, Luigi A., Rombolà, Laura, Amantea, Diana, Russo, Rossella, Berliocchi, Laura, Sakurada, Shinobu, Rotiroti, Domenicantonio and Corasaniti, Maria T. Neuropharmacology of the essential oil of bergamot. Fitoterapia. 2010;81(6): 453- 61.

3. Sen, T., \&Samanta, S. K. Medicinal plants, human health and biodiversity: a broad review. In Biotechnological Applications of Biodiversity. 2014;59-110.

4. Ayo, R. G. Phytochemical constituents and bioactivities of the extracts of Cassia nigricans Vahl: A review. Journal of medicinal plants research. 2010;4(14), 1339-1348.

5. Veerachari, U.,\&Bopaiah, A. K. Preliminary phytochemical evaluation of the leaf extract of five Cassia species. Journal of Chemical and Pharmacology Research. 2011;3(5), 574-583.

6. Hyldgaard M, Mygind T, Meyer RL. Essential oils in food preservation: mode of action, synergies, and interactions with food matrix components. Front Microbiol. 2012; 3:12.

7. Aramesh $\mathrm{M}$, Ajoudanifar $\mathrm{H}$. Alkaline protease producing Bacillus isolation and identification from Iran, Banat's Journal of Biotechnology. 2017;8 (16), 140-147.

8. Costa, Ane R. T., Amaral, Mônica F. Z. J., Martins, Paula M., Paula, Joelma A. M., Fiuza, Tatiana S., Tresvenzol, Leonice M. F., Paula, José R. and Bara, Maria Tereza F. Essential oil action Syzygiumaromaticum (L.) Perry on the hyphae of some pathogenic fungi. Brazilian Journal of Medicinal Plant. 2011;13: 240- 45. 
9. Tajkarimi, M. M., Ibrahim, S. A., and Cliver, D. O. Antimicrobial herb and spice compounds in food. Food Control. 2010;21, 1199-1218.

10. Sadaka F, Nguimjeu C, Brachais CH, Vroman I, Tighzert L, Couvercelle JP. Review on antimicrobial packaging containing essential oils and their active biomolecules. Innovative Food Science \& Emerging Technologies. 2014;1 -9

11. Ganjewala, D.; Sam, S.; Khan, K.H. Biochemical compositions and antibacterial activities of Lantana camara plants with yellow, lavender, red and white flowers. EurAsian Journal of BioSciences. 2009;3, 6977 .

12. Thamotharan, G., Ganesh, T., Sen, S., Thilagam, E., Loganathan, T., \& Chakraborty, R. Pharmacognostic and anti-hyperglycemic evaluation of Lantana camara (L.) var. aculeate leaves in alloxan-induced hyperglycemic rats. International Journal of Research in Pharmaceutical Sciences. 2010;1(3), 247-252.

13. Wurochekke, A. U., Anthony, A. E., \&Obidah, W. Biochemical effects on the liver and kidney of rats administered aqueous stem bark extract of Xemenia Americana. African Journal of Biotechnology. 2008;7(16).

14. Deepak, G., Silviya, S. and Kishwar, H. K. Biochemical compositions and antibacterial activities of Lantana camara plants with yellow lavender, red and white flowers. Eurasian Journal of Bioscience. 2009;3: 69-77.

15. Saxena M., Saxena J. and Khare S. Therapeutical values of Lantana camara plant. International journal of pharmacy \& life sciences. 2012;3(3): 1551-1554.

16. Rwangabo P.C. Umuhengerin. A new antimicrobially active flavonoid from Lantana trifolia. Journal of Natural Product. 1998;51: 966-968.

17. Ross, R. Atherosclerosis-an inflammatory disease. New England journal of medicine. 1999;340(2), 115-126.

18. Banerjee, Sarmistha, Panda, Chinmay K. and Das, Sukta. Clove. (Syzygiumaromaticum L.), a potencialchemopreventive agent for lung cancer. Carcinogenesis. 2006;27 (8): 1645- 54.

19. Gutierrez, J., Barry-Ryan, C. and Bourke, P. The anti-microbial efficacy of plant essential oil combinations and interactions with food ingredients. International Journal of Food Microbiology. 2008;124: 91-97.

20. Gill, A.O. and Holley, R.A. Disruption of E. coli, Listeria monocytogenes and Lactobacillus sakei cellular membranes by plant oil aromatics. International Journal of Food Microbiology. 2006;108: 1-9 
21. Sánchez, E., García, S., and Heredia, N. Extracts of edible and medicinal plants damage membranes of Vibrio cholerae. Appl. Environ. Microbiol. 2010;76, 6888-6894.

22. Nikkon, F., Saud, Z. A., Rehman, M. H., \&Haque, M. E. In vitro antimicrobial activity of the compound isolated from chloroform extract of Moringa oleifera Lam. Pakistan Journal of Biological Science. 2003;22: 1888-1890.

23. Trombetta, D., Castelli, F., Sarpietro, M.G., Venuti, V., Cristani, M., Daniele, C., Saija, A., Mazzanti, G. and Bisignano, G. Mechanisms of antibacterial action of three monoterpenes. Antimicrobial Agents and Chemotherapy. 2005;49: 2474-2478.

24. Adegoke, S. A., Agada, F. D., \&Ogundipe, L. O. Antibacterial activity of methanol and ethanol leaf extracts of Antidesma venosum and Lanneabarteri. African Journal of Microbiology Research. 2013;7(27), 3442-3447.

25. Owokotomo, I. A., Ekundayo, O., Abayomi, T. G., \&Chukwuka, A. V. In-vitro anti-cholinesterase activity of essential oil from four tropical medicinal plants. Toxicology reports. 2015;2, 850-857.

26. Semwal, P., and Painuli, S. Antioxidant, antimicrobial, and GC MS profiling of Saussureaobvallata(Brahma Kamal) from Uttarakhand Himalaya. Clin. Phytosci. 2019;5, 1-11. doi:10.1186/s40816-019-0105-3

27. Geetha, N., Kaviyarasu, K., Kanimozhi, K., Magdalane, C. M., Sivaranjani, S., Ayeshamariam, A. \&Maaza, M. In vitro cytotoxicity effect and antibacterial performance of human lung epithelial cells A549 activity of zinc oxide doped TiO2 nanocrystals: investigation of bio-medical application by chemical method. Materials Science and Engineering. 2017;74: 325-333.

28. Zénabou, S., Jean, K., Gilles, F., Cheikna, Z., Marius, S. K., \& Alfred, T. S. Chemical composition, antioxidant and antimicrobial activities of Lantana camara Linn leaves essential oil from Burkina Faso. GSC Biological and Pharmaceutical Sciences. 2018;5(3): 124-135.

29. Jawonisi, I. O., \&Adoga, G. I. Chemical Constituents of Essential Oil of" Lantana camara Linn." Leaves. British Journal of Pharmacology and Toxicology. 2013;4(4), 155-157.

30. Elansary, H. O., Salem, M. Z., Ashmawy, N. A., \&Yacout, M. M. Chemical composition, antibacterial and antioxidant activities of leaves essential oils from Syzygiumcumini L., Cupressus sempervirens L. and Lantana camara L. from Egypt. Journal of Agricultural science. . 2012;4(10), 144.

31. Rabindra, K. S., \&Balendra, T. Composition of Lantana camara leaf essential oil. International Journal of Pharmaceutical Research and Development. 2011;3(7), 51-55.

32. Adjou, E. S., Dahouenon-Ahoussi, E., Degnon, R. G., Soumanou, M. M., \&Sohounhloue, D. C. K. Bioefficacy of essential oil of Lantana camara from Benin against the growth of fungi and aflatoxin production. Journal of Advanced Agriculture. 2012;1: 112-121. 
33. Ikeura, Y., Kurihara, K., \&Kunitake, T. Molecular recognition at the air-water interface. Specific binding of nitrogen aromatics and amino acids by monolayers of Long-chain derivatives of Kemp's acid. Journal of the American Chemical Society. 1991;113(19), 7342-7350.

34. Altemimi, A., Lakhssassi, N., Baharlouei, A., Watson, D. G., \&Lightfoot, D. A. Phytochemicals:

Extraction, isolation, and identification of bioactive compounds from plant extracts. Plants. 2017;6(4): 42.

35. Cheynier, V., Comte, G., Davies, K. M., Lattanzio, V., and Martens, S. Plant phenolics: Recent advances on their biosynthesis, genetics, and ecophysiology. Plant Physiol. Biochem. 2013;72,1-20. doi:10.1016/j. plaphy.2013.05.009

36. Zénabou, S., Jean, K., Gilles, F., Cheikna, Z., Marius, S. K., \& Alfred, T. S. Chemical composition, antioxidant and antimicrobial activities of Lantana camara Linn leaves essential oil from Burkina Faso. GSC Biological and Pharmaceutica/ Sciences. 2018;5(3): 124-135.

37. Sousa, E. O., Miranda, C. M., Nobre, C. B., Boligon, A. A., Athayde, M. L., \& Costa, J. G. Phytochemical analysis and antioxidant activities of Lantana camara and Lantana montevidensis extracts. Industrial Crops and Products. 2015;70: 7-15.

38. Sonibare, O. O., \& Effiong, I. Antibacterial activity and cytotoxicity of essential oil of Lantana camara L. leaves from Nigeria. African Journal of Biotechnology. 2008;7(15).

39 Saikia, A. K., \&Sahoo, R. K. Chemical composition and antibacterial activity of essential oil of Lantana camara L. Middle-East Journal of Scientific Research. 2011;8(3), 599-602.

40. Sousa, E. O., Viana, A. C., Rodrigues, F. F., Campos, A. R., Lima, S. G., \& Costa, J. G. M. Effect of collection time on essential oil composition of Lantana camara Linn (Verbenaceae) growing in Brazil Northeastern. Records of Natural Products. 2010;4(1), 31.

41. Zandi-Sohani, N., Hojjati, M., \&Carbonell-Barrachina, Á. A. Bioactivity of Lantana camara L. essential oil against Callosobruchus maculatus (Fabricius). Chilean Journal of Agricultural Research. 2012;72(4), 502.

42. Da Silva, M. H. L., Andrade, E. H. A., Zoghbi, M. D. G. B., Luz, A. I. R., da Silva, J. D., \& Maia, J. G. S. The essential oils of Lantana camara L. occurring in North Brazil. Flavour and fragrance journal. 1999;14(4): 208-210.

43. Marongiu, R., Ferraris, A., lalongo, T., Michiorri, S., Soleti, F., Ferrari, F. \&Antonini, A. PINK1 heterozygous rare variants: prevalence, significance and phenotypic spectrum. Human mutation. 2008;29(4), 565-565.

44. Khan, M., Mahmood, A., \&Alkhathlan, H. Z. Characterization of leaves and flowers volatile constituents of Lantana camara growing in central region of Saudi Arabia. Arabian Journal of Chemistry. 2016;9(6), 764-774. 
45. Badakhshan MP, Sasidharan S, Rameshwar NJ, Ramanathan S. A. Comparative study: antimicrobial activity of methanol extracts of Lantana camara various parts. Pharmacognosy Research. 2009; 1 (6):348-351.

46. Vivek, M.N., Swamy, S.H.C., Manasa, M., Pallavi, S., Kambar, Y., Asha, M.M. et al. Antimicrobial and Antioxidant activity of leaf and flower extract of Caesalpinia pulcherrima, Delonix regia and Peltaphorum ferrugineum. J. Appl. Pharma Sci. 2013;3:64-71. doi:10.7324/JAPS.2013.3811

47. Nikaido, H. Porins and specific channels of bacterial outer membranes. Molecular microbiology. 1992;6(4), 435-442.

48. Sangeetha M., Mahendra C., Ushadevi C. An overview on the medicinal properties of Lantana Camara Linn. International Journal of innovative pharmaceutical science and research. 2015;3(5): 645-654

49. Tiwari, B.K., Valdramidis, V.P., O'Donnel, C.P., Muthukumarappan, K., Bourke, P. and Cullen, P.J. Application of natural antimicrobials for food preservation. Journal of Agricultural and Food Chemistry. 2009;57: 5987-6000.

50. Zoubiri, S., and A. Baaliouamer. GC and GC/MS analyses of the Algerian Lantana camara leaf essential oil: Effect against Sitophilus granariusadults. Journal of Saudi Chemical Society, 2011; doi:10.1016/j.jscs.2011.01.013.

51. Magaldi, S., Mata-Essayag, S., De Capriles, C. H., Perez, C., Colella, M. T., Olaizola, C., \& Ontiveros, Y. Well diffusion for antifungal susceptibility testing. International journal of infectious diseases. 2004;8(1): 39-45.

52. Valgas, C., Souza, S. M. D., Smânia, E. F., \&Smânia Jr, A. Screening methods to determine antibacterial activity of natural products. Brazilian Journal of Microbiology. 2007;38(2), 369-380.

\section{Tables}


Table 1

UV Spectra Data for the Essential oil from Lantana camara

\begin{tabular}{|lll|}
\hline S/N & Wavelength $(\mathrm{nm})$ & Absorbance $\left(\mathrm{cm}^{-1}\right)$ \\
\hline 1 & 808.00 & 0.209 \\
\hline 2 & 669.00 & 0.218 \\
\hline 3 & 366.50 & 0.304 \\
\hline 4 & 342.00 & 0.352 \\
\hline 5 & 235.00 & 4.002 \\
\hline 6 & 227.00 & 4.001 \\
\hline 7 & 205.00 & 4.008 \\
\hline 8 & 762.50 & 0.206 \\
\hline 9 & 748.50 & 0.206 \\
\hline 10 & 363.50 & 0.304 \\
\hline 11 & 338.00 & 0.345 \\
\hline 12 & 231.00 & 3.997 \\
\hline 13 & 211.00 & 3.981 \\
\hline
\end{tabular}


Table 2

Chemical composition of Lantana camara Essential oil

\begin{tabular}{|c|c|c|c|}
\hline$S / N$ & $\begin{array}{l}\text { Retention time } \\
\text { (min) }\end{array}$ & Phytochemical Constituent & $\begin{array}{l}\text { Composition } \\
(\%)\end{array}$ \\
\hline 1 & 3.065 & 3-Hexen-1-ol & 0.52 \\
\hline 2 & 3.176 & 2-Hexen-1-ol & 0.36 \\
\hline 3 & 3.776 & a-pinene & 6.26 \\
\hline 4 & 3.917 & Camphene & 4.04 \\
\hline 5 & 4.361 & $\beta$-phenandrene & 9.28 \\
\hline 6 & 4.435 & $\beta$-mycrene & 2.78 \\
\hline 7 & 4.650 & 3-carene & 6.46 \\
\hline 8 & 4.902 & 2-butenylcyclopropane & 3.72 \\
\hline 9 & 5.087 & Eucalyptol & 6.61 \\
\hline 10 & 5.206 & $\beta$-ocimene & 1.79 \\
\hline 11 & 5.346 & $\mathrm{Y}$-terpinene & 1.22 \\
\hline 12 & 5.509 & Terpinen-4-ol & 2.22 \\
\hline 13 & 5.746 & 2-carene & 1.22 \\
\hline 14 & 5.924 & Linalool & 2.31 \\
\hline 15 & 6.065 & Ipsdienol & 0.09 \\
\hline 16 & 6.213 & Isopulegol & 0.37 \\
\hline 17 & 6.450 & Camphor & 3.24 \\
\hline 18 & 6.731 & Endoborneol & 5.04 \\
\hline 19 & 6.931 & a-terpineol & 2.56 \\
\hline 20 & 7.043 & Verbenone & 0.51 \\
\hline 21 & 7.257 & Citral B/Neral & 0.14 \\
\hline 22 & 7.368 & Piperitone & 0.13 \\
\hline 23 & 7.472 & Citral A/Geranial & 0.17 \\
\hline 24 & 7.583 & Selinene & 0.06 \\
\hline 25 & 7.650 & Indole & 0.07 \\
\hline 26 & 7.717 & Cumyl alcohol & 0.11 \\
\hline
\end{tabular}




\begin{tabular}{|c|c|c|c|}
\hline $\mathrm{S} / \mathrm{N}$ & $\begin{array}{l}\text { Retention time } \\
\text { (min) }\end{array}$ & Phytochemical Constituent & $\begin{array}{l}\text { Composition } \\
\text { (\%) }\end{array}$ \\
\hline 27 & 7.931 & Isoterpinolene & 0.72 \\
\hline 28 & 8.050 & Eugenol & 0.37 \\
\hline 29 & 8.272 & $\beta$-elemene & 3.26 \\
\hline 30 & 8.524 & Caryophyllene & 4.95 \\
\hline 31 & 8.679 & Humulene & 3.09 \\
\hline 32 & 8.783 & $\beta$-copaene & 2.17 \\
\hline 33 & 8.887 & Bicyclogermacrene & 4.11 \\
\hline 34 & 9.131 & Nerolidol/Peruviol & 3.92 \\
\hline 36 & 9.376 & Cyclopentanol 1-(1-methylene-2-propenyl) & 2.34 \\
\hline 37 & 9.472 & 2-octyne & 3.04 \\
\hline 38 & 9.561 & $\begin{array}{l}\text { 1,3-Bis-(2-cyclopropyl-2-methylcyclopropyl)-but-2-en- } \\
\text { 1-one }\end{array}$ & 4.18 \\
\hline 39 & 9.635 & 2-butenylcyclopropane & 2.46 \\
\hline 40 & 9.842 & Bisabolene epoxide & 0.40 \\
\hline 41 & 9.953 & Dichlorovinyltrimethylsilane & 0.83 \\
\hline 42 & 10.146 & Carophyllene oxide & 0.23 \\
\hline 43 & 10.316 & Linolenic acid & 0.27 \\
\hline 44 & 10.524 & Palmitic acid & 0.13 \\
\hline 45 & 10.768 & Nerolidol & 0.22 \\
\hline 46 & 10.916 & Hortrienol & 0.26 \\
\hline 47 & 11.020 & Phytol & 0.54 \\
\hline 49 & 11.427 & 1-methyl bicycle $(3,2,1)$ octane & 0.09 \\
\hline 50 & 11.590 & Oleamide & 0.05 \\
\hline 51 & 11.990 & 9-octadenamide & 0.06 \\
\hline
\end{tabular}

\section{Figures}




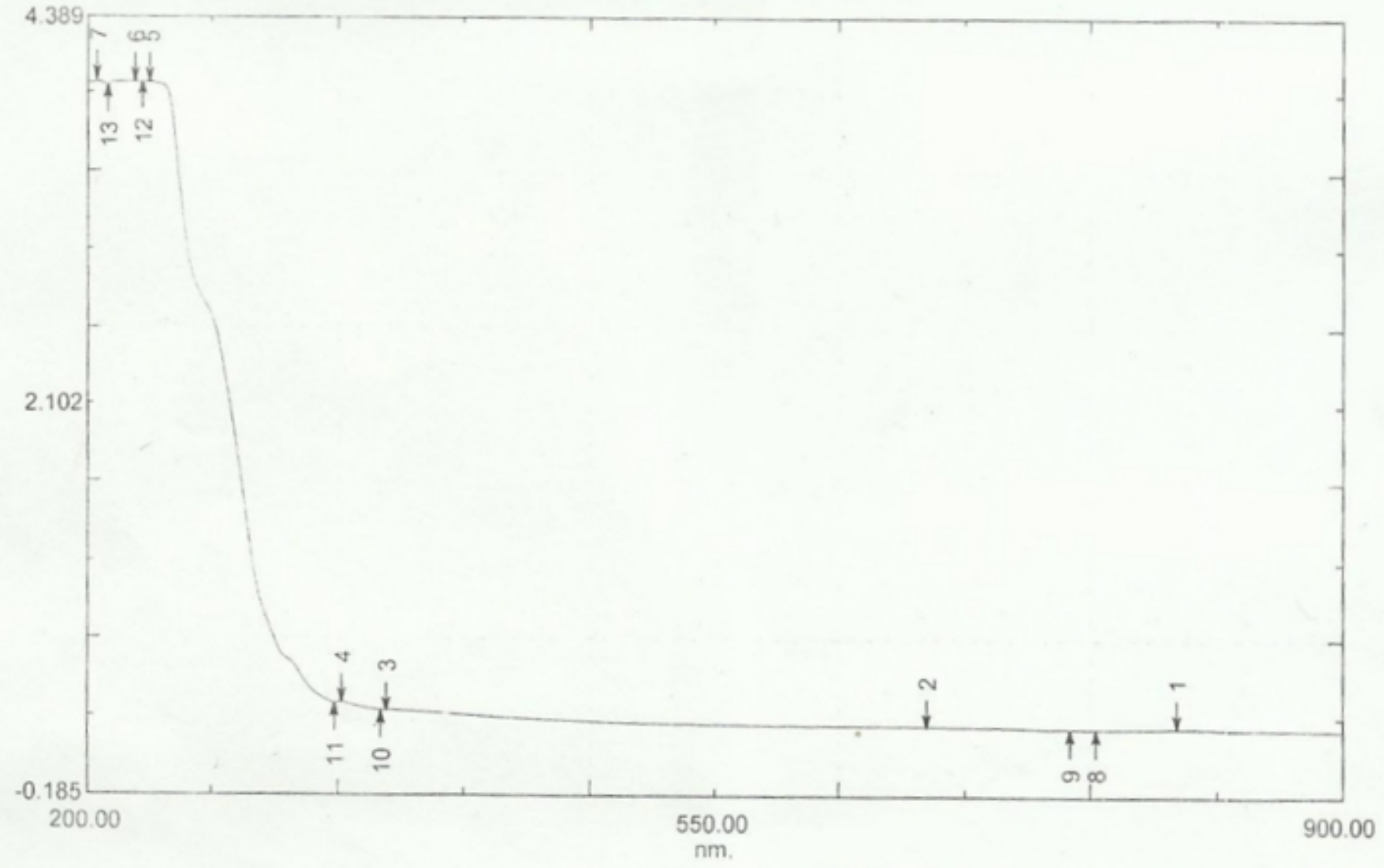

Figure 1

UV-Visible spectra of Lantana camara essential oil

UV-Visible spectrophotometer Result and Analysis

UV-Visible spectra analysis 


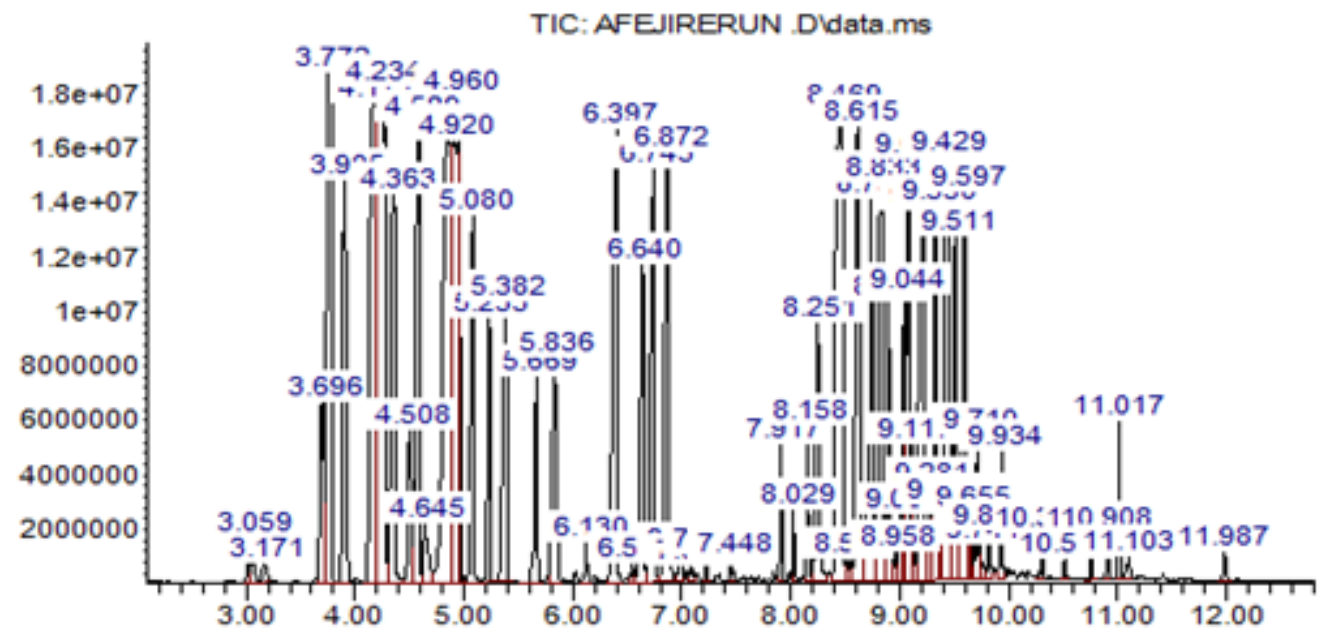

Time-->

Abundance

TIC: AFEJIRERUN Dldatasimms

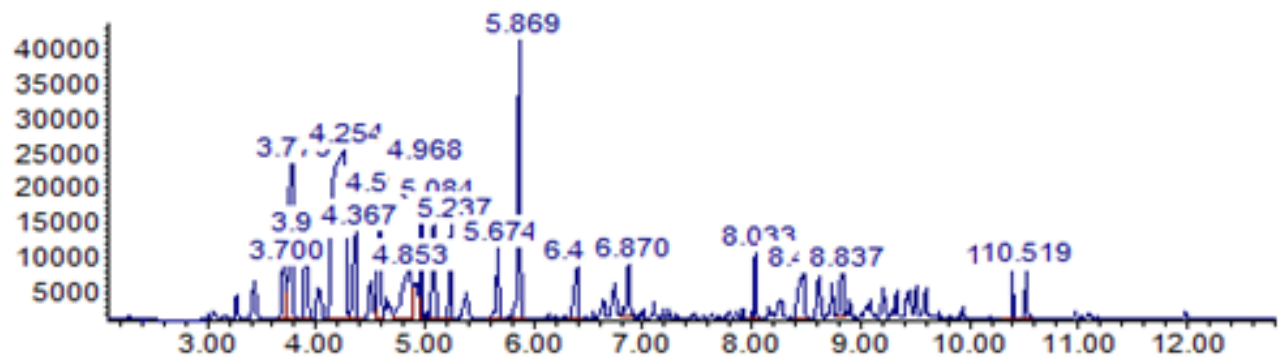

Time $\rightarrow$

Figure 2

GC-MS graph of lantana camara essential oil

GC-MS results and Chemical Composition of Essential oil

GC-MS graph 


\section{Zone Inhibition of Lantana camara essential oil on selected bacteria}

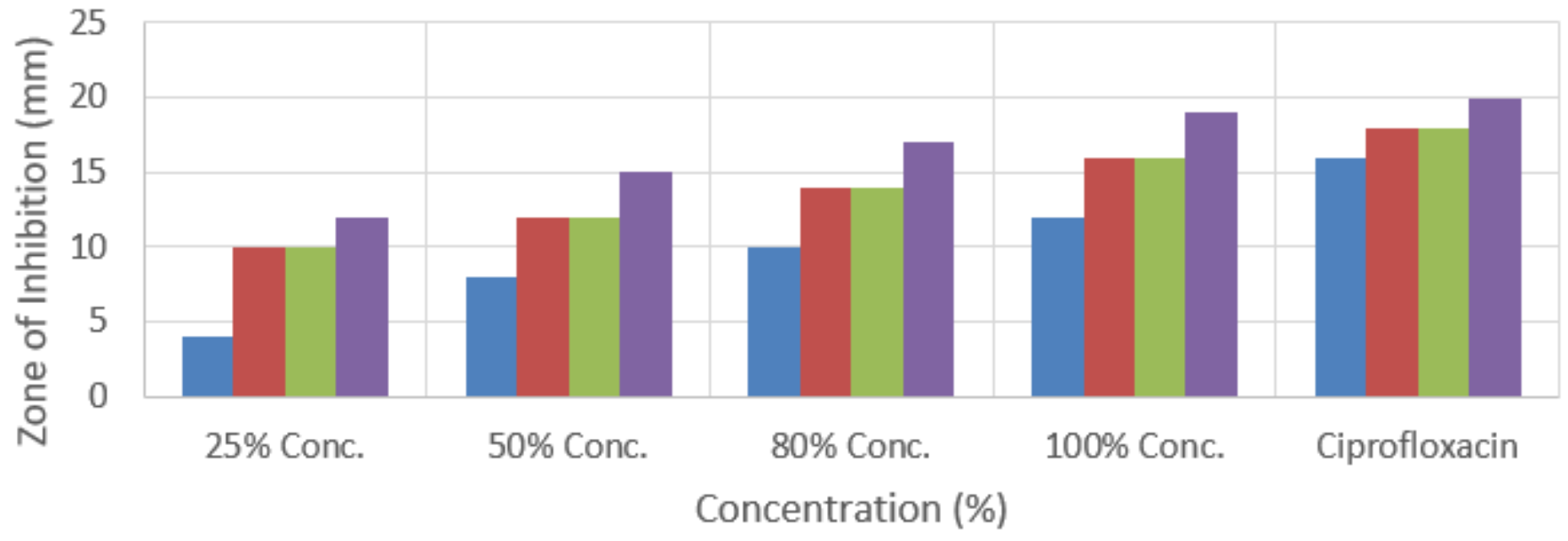

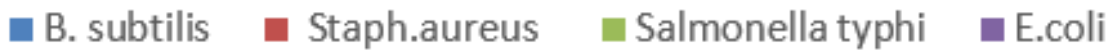

Figure 3

Zone Inhibition of Lantana camara essential oil of selected bacteria

\section{Zone of inhibition exhibited by Oil extracts}

The potency of antibiotics to inhibit bacterial growth is quantifying by agar diffusion assay. ${ }^{52}$

\section{Result}




\section{Minimum Inhibitory Concentration (MIC) of Lantana camara essential oil}

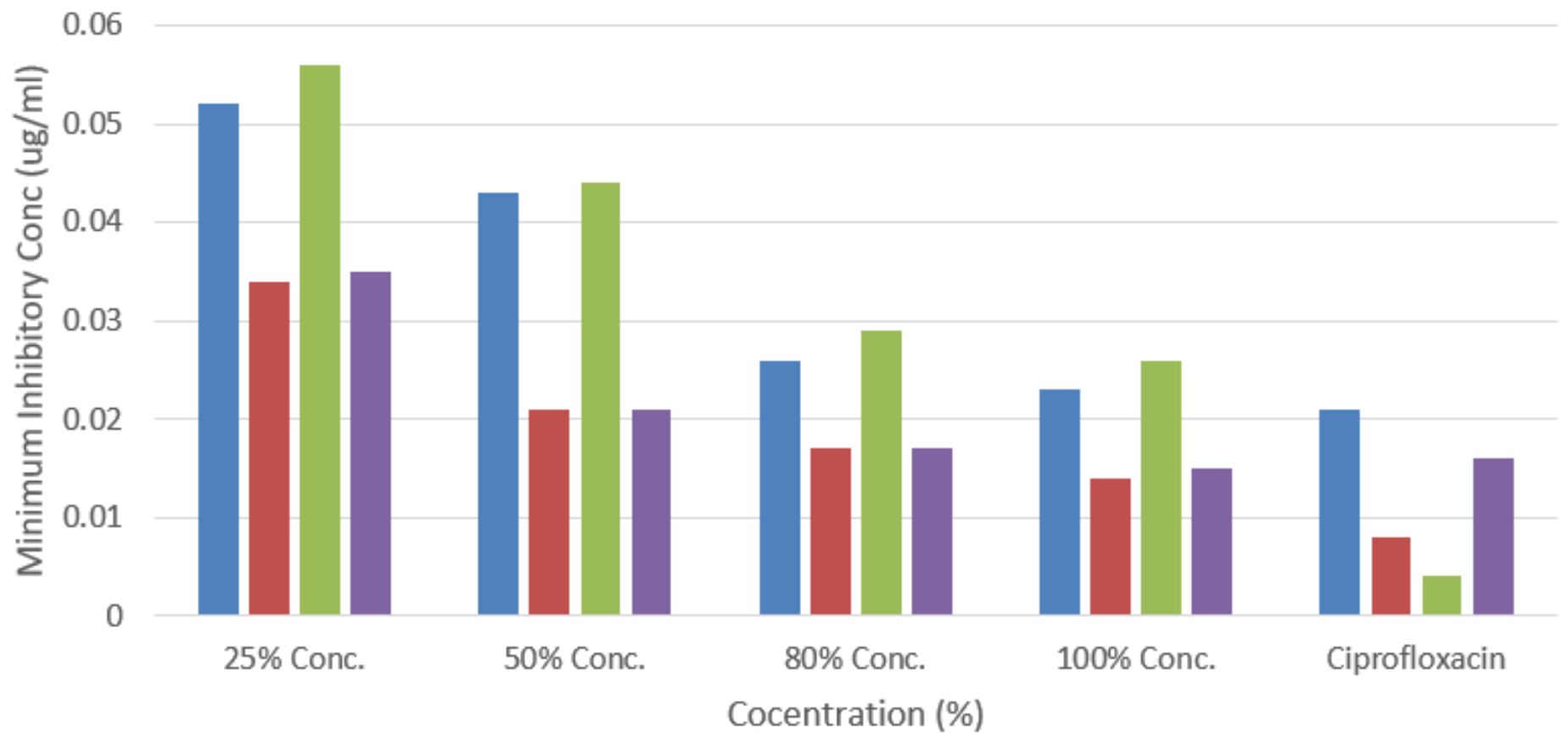

B. subtilis astaph.aureus a salmonella typhi $\quad$ E.coli

Figure 4

Minimum Inhibitory Concentration of Lantana camara essential oil 